\title{
Intercolony and seasonal differences in the breeding diet of European shags on the Galician coast (NW Spain)
}

\author{
Alberto Velando ${ }^{1}$, Juan Freire ${ }^{2, *}$ \\ ${ }^{1}$ Departamento de Ecoloxía e Bioloxía Animal, Universidade de Vigo, 16200 Vigo, Spain \\ ${ }^{2}$ Departamento de Bioloxía Animal, Bioloxía Vexetal e Ecoloxía, Universidade da Coruña, 15071 A Coruña, Spaín
}

\begin{abstract}
The seasonal and spatial variations in the diet of the European shag Phalacrocorax aristotelis were studied during the breeding period, based on the analysis of 202 adults' pellets (February to June, 1995) and 30 regurgitations of chicks (April, May and June, 1995 and 1996) taken from 2 colonies located in close proximity to one another $(<15 \mathrm{~km}$ ) on the coast of Galicia (NW Spain; Islands of Cíes and Ons). The diet of birds from the Cíes Islands consisted mainly of sandeels (family Ammodytidae), which make up over $70 \%$ of the prey during all months. These fishes went practically unreported in a number of previous studies of fish communities in the region, probably due to the low catchability of trawl nets and the possibility that the habitats of sandeels where shags forage, shallow $k 10$ to $15 \mathrm{~m}$ ) sandy bottoms, were not sampled adequately. Seasonal changes were found on the Island of Ons, where in winter (February and March) the diet was based on gobids (family Gobiidae) and sand smelts Atherina presbyter, while in spring the dominant prey were the Ammodytidae (in May and June they made up over $86 \%$ ). The consumption of sandeels established an increased similarity in diet between the colonies throughout the breeding cycle, and they were the only prey whose abundance was negatively correlated with the diversity of each pellet. This study highlights the high plasticity in prey and feeding habitats (both pelagic and benthic with different types of substrates) used by the European shag. It should be noted, however, that the main prey during chick rearing are sandeels. Differences were found in the mean sizes of the different prey consumed, but the modal size for all of them throughout the season was around 9 to $11 \mathrm{~cm}$ in total length. The range of sizes available in the environment is greater than the range chosen by the European shag, which suggests that this bird selects a narrow range of prey sizes.
\end{abstract}

KEY WORDS: Diet - Breeding · Seasonal changes - Spatial changes · Fish prey $\cdot$ Prey size - European shag · Galicia (NW Spain)

\section{INTRODUCTION}

Seabirds are upper trophic level consumers and there has been increasing interest in the roles they play in marine ecosystems and in their predator-prey relationships (e.g. Croxall et al. 1985, Schneider et al. 1985, Croxall 1987). Thus, seabirds have been used in several geographical areas to detect ecosystem changes (e.g. Barret \& Schei 1977, Ollason \& Dunnet 1983, Harris \& Wanless 1990, Huntley et al. 1991,

-Addressee for correspondence.

E-mail: jfreire@udc.es
Aebischer \& Wanless 1992, Monaghan 1996, Montevecchi \& Myers 1996, 1997) and as indicators of prey abundance (Cairns 1987, Barret et al. 1990, Hatch \& Sanger 1992, Montevecchi \& Myers 1995).

The European shag Phalacrocorax aristotelis has a distribution restricted to the Western Palearctic, from the North Cape (Norway) to the coast of Morocco (Lloyd et al. 1991). The nominal subspecies ( $P$. aristotelis aristotelis) breeds on the Atlantic coast and its distribution limit is located on the Iberian Peninsula (Bernis 1948). Galicia (NW Spain) has a population of approximately 2000 pairs, $85 \%$ of which are concentrated on the Islands of Cies and Ons (Velando 1997). 
The European shag is the most abundant bird on the Galician coasts that has exclusively marine feeding habits.

European shags typically use foot propulsion (Ashmole 1971) to feed on the bottom (Wanless et al. 1993a), although shags spend about half their time in pelagic dives (Grémillet et al. 1998). Foraging areas have depths ranging between 7 and $80 \mathrm{~m}$ (Guyot 1988, Barret \& Furness 1990, Wanless et al. 1991a, 1993a), with a mean of approximately 20 to $30 \mathrm{~m}$ (Wanless et al. 1997), and have mean and maximum radii of 7 and $17 \mathrm{~km}$ from colonies (Wanless et al. 1991b). Many studies have focused on the diet composition of the European shag. The first study was carried out by Steven (1933), who used an analysis of stomach contents in an attempt to determine the impact of this species on stocks of commercial fish. The diet of the European shag has been used to assess the recruitment and abundance of fish populations (Barret et al. 1990, Barret 1991). This

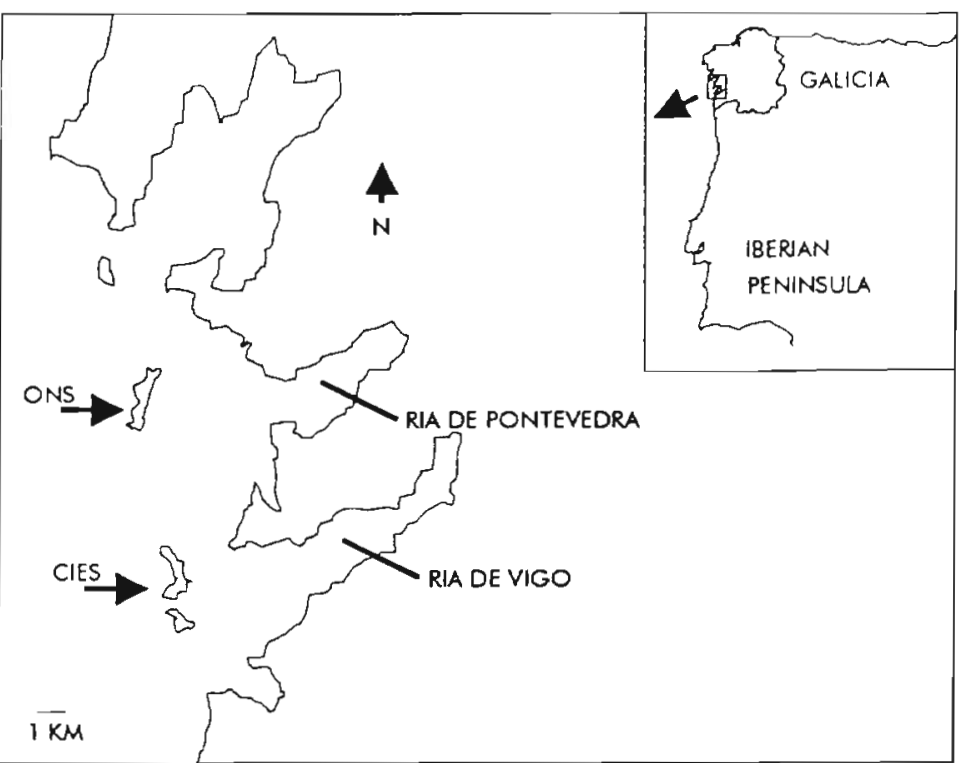

Fig. 1. Location on the Iberian Peninsula of the colonies of European shag Phalacrocorax aristotelis on the lslands of Cies and Ons, where the dietary study was carried out species feeds on a wide-ranging variety of benthic, demersal and schooling pelagic fish, which is the reason for its classification as opportunistic in its feeding habits (Barret 1991, Grémillet et al. 1998). The most common prey during the breeding season are different species of sandeel (family Ammodytidae) (Steven 1933, Lumsden \& Haddow 1946, Snow 1960, Pearson 1968, Rae 1969, Harris \& Wanless 1991), although gadids are also important components of their diet in Norway (Barret et al. 1990). The diet of the European shag varies depending on annual changes in prey availability (Carss 1993) and, to a lesser extent, on location. Data presented by Lumsden \& Haddow (1946) show that specific composition of the diet varied depending on the type of marine substrate where the prey had been caught, suggesting that the type of bottom determines the type of fish that will be found in a particular location. The diet of adults of this species has been well documented on Arctic coasts (Barret et al. 1990), British coasts (Steven 1933, Lumsden \& Haddow 1946, Pearson 1968, Mills 1969, Harris \& Riddiford 1989, Harris \& Wanless 1991 , 1993), and in the Mediterranean (Guyot 1988). On the Iberian Peninsula, however, there is no information available on the diet of this species, except for preliminary information from Asturias (N Spain) (Álvarez 1998).

The present study examines the diet composition of the European shag throughout the breeding cycle and the differences between the 2 Galician colonies in close proximity to one another $(<15 \mathrm{~km})$. The dietary study was based on analysis of the regurgitations of chicks and the pellets of adults. These methods were chosen because they offer the possibility of acquiring a wealth of information with a minimum of disturbance to the population and, although they are limited indicators of diet, they have been recognized as appropriate methods for the temporal and spatial comparison of the diet of the European shag (Duffy \& Laurenson 1983, Barret et al. 1990, Barret 1991).

\section{MATERIALS AND METHODS}

The study was carried out on 2 breeding colonies in Galicia (NW Spain): (1) the Cies Islands (42 $15^{\prime} 04^{\prime \prime} \mathrm{N}$, $8^{\circ} 53^{\prime} 30^{\prime \prime} \mathrm{W}$ ), which are located in the outer area of the Ría de Vigo and are the breeding grounds for over 1000 pairs, and (2) the Island of Ons (42 $21^{\prime} 05^{\prime \prime} \mathrm{N}$, $5^{\circ} 15^{\prime} 35^{\prime \prime} \mathrm{W}$ ) located in the Ría de Pontevedra, where over 600 pairs breed (Fig. 1). The egg laying season of the European shag on these islands in 1995 and 1996, the years in which the study was carried out, reached its peak on 25 and 20 March, respectively, and the chicks began feeding a month later (Velando 1997).

The diet was analyzed by collecting pellets every 15 $\mathrm{d}$ on the Cíes Islands and monthly on the Island of Ons between February and June 1995, and regurgitations of the nestlings only in the Cíes Islands in April, May and June of 1995 and 1996. A total of 202 pellets (127 on the Cies Islands and 75 on the Island of Ons) and 30 spontaneous regurgitations were collected. All of the pellets were fresh and showed no signs of deterioration 
or drying. On each sampling occasion each pellet was taken from a different nest. Hard parts in the pellets were separated from the other remains and identified with a stereoscopic microscope, to the lowest taxonomic level possible. Fish prey were identified using sagittal otoliths and pharyngeal teeth by means of the otolith keys of Bauza (1962) and Härkönen (1986) and our own collections of otoliths and pharyngeal teeth for labrids. Otoliths have been used in many studies to identify fish prey and to estimate their body sizes and biomasses (e.g. in Duffy \& Jackson 1986, Härkönen 1986, Jobling \& Breiby 1986, Pierce \& Boyle 1991).

Diet composition was expressed as the proportion of items belonging to each prey type, such as otoliths, pharyngeal teeth, upper beaks in cephalopods, etc., considering items as paired structures for identification. In the case of crustaceans, of which only gammarid amphipods were observed, the number of prey was counted.

The level of taxonomic resolution for identification was different for each prey type. The family Ammodytidae was treated as 1 category, as the species that make up this family are difficult to identify because the otoliths are very similar and the slight impression of the saculus is lost when they are partially eroded. The small number of otoliths belonging to this family identified at the species level were mainly Gymnammodytes semisquamatus and, to a lesser extent, Hyperoplus lanceolatus. The species of the genus Gobius and Lesueurigobius friesii were included within the category Gobius spp. The category Symphodus spp. was comprised of $S$. cinereus and $S$. melops. Both species have very similar otoliths and pharyngeal teeth, but they can be differentiated from $S$. bailloni. Trisopterus spp. may include both T. luscus and $T$. minutus, although the few otoliths that were identified pertained to $T$. luscus. Non-cephalopod molluscs were not included in the analysis as in most cases only the shell was present, and these could serve as gastroliths like the stones found in many pellets.

The partial erosion of otoliths caused by digestion could result in the underestimation of the sizes of prey consumed (Johnstone et al. 1990). In order to reduce this effect, only those otoliths that did not show signs of excessive erosion were measured by means of an image analysis system (Electron Microscopy Unit, Universidade da Coruña). The measurements obtained using this system did not differ significantly from those found using a stereoscopic microscope with a graduated eyepiece. The mass and total length of each prey was estimated by means of published equations that relate otolith size to the body size and mass of fish (Härkönen 1986). For the sand smelt Atherina presbyter the equations were calculated from unpublished data provided by S. Lens (Instituto Español de Oceano- grafía, Vigo). In taxa that included several species, the equation pertaining to the most frequent species in the diet was used. In order to estimate the mass of prey with deteriorated otoliths, a mean value of the mass of all analyzed samples was assigned to that prey. For prey without mass equations, a mean value of the mass obtained for all prey was assigned.

The importance of each prey in the diet was estimated as numerical frequency $(\% \mathrm{~N}$, the total percentage of items constituted by each category) and percentage of biomass $(\% \mathrm{~B}$, as compared to the total biomass). The numerical frequency of the different types of prey was compared between months and islands using the G-test (Sokal \& Rohlf 1995). To compute this test, different prey species were grouped by family, including 2 groups of uncommon prey ('invertebrates' and 'other fishes'). The standardized residuals in the tests made it possible to identify prey categories which determine the quantitative importance of the differences between samples.

The Shannon-Wiener diversity index (Tramer 1969) was used to describe the diversity of diet:

$$
H^{\prime}=-\sum p_{i}\left(\ln p_{i}\right)
$$

where $p_{\mathrm{i}}$ is the proportion of all the items in the sample belonging to category $i$. Individual diversity ( $\left.H_{\text {ind }}^{\prime}\right)$ for each pellet, and population diversity ( $\left.H_{\text {pop }}^{\prime}\right)$, referring to the total number of pellets, were calculated. A mean estimate of population diversity $\left(H_{\text {jack }}^{\prime}\right)$ was obtained by using the jackknife procedure (Krebs 1989). Both the similarity and diversity indices were calculated using the prey groups that had the highest identification level.

Both parametric and non-parametric statistical tests were used, depending on the normality of the samples (Kolmogorov-Smirnov tests). The individual diversity index was compared between locations and among months using the Kruskal-Wallis and Mann-Whitney tests. Spearman rank correlations were established between individual diversity and the frequency of each prey in the pellet. The indices obtained by the jackknife method were compared between locations and among months with a 2-way ANOVA. The LSD test (least significant difference) was used as an a posteriori 1-way ANOVA (Sokal \& Rohlf 1995). A correspondence analysis was carried out using each pellet analyzed as a case and the natural logarithm of the number of items of each prey as variables. Prey consisting of over $1 \%$ of the total items were selected and the rare categories were downweighted. The following prey were selected: Ammodytidae (Am), Atherina presbyter (Ath), Gobius spp. (Gob), Gobiusculus flavescens (Gbs), Symphodus spp. (Sym), Symphodus bailloni (Syb), Trisopterus spp. (Tri) and Pollachius pol- 

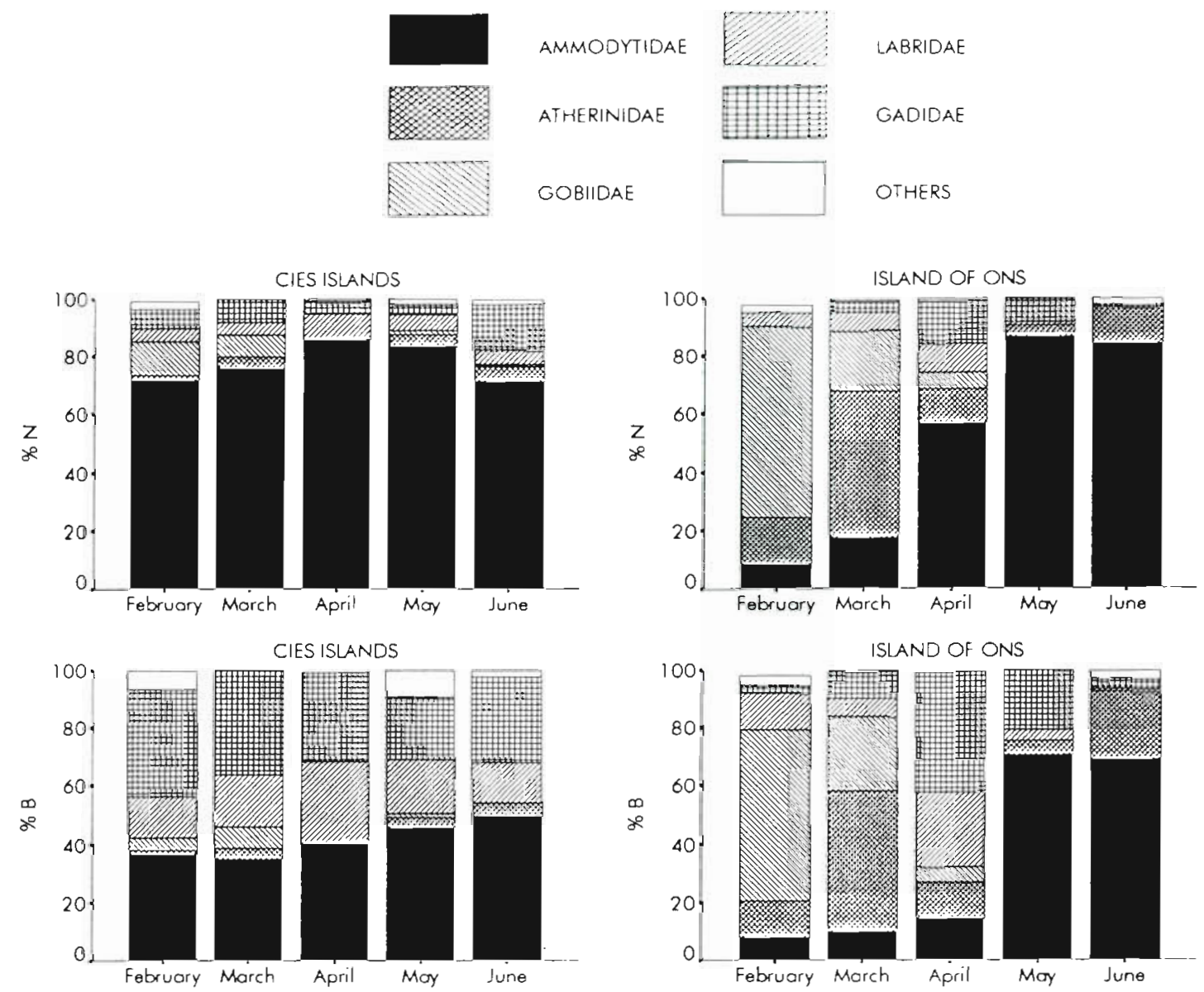

Fig. 2. Phalacrocorax aristotelis. Temporal evolution of the diet composition (expressed as numerical frequency, \% N) and percentage of mass $(\% \mathrm{~B})$ of the European shag on the Islands of Cies and Ons during the study period

lachius (Pll). The correspondence analysis was carried out with the software CANOCO v. 3.11 (ter Braak 1988)

Measurements of undigested otoliths were used to calculate prey size frequency distributions. A 2-way (month and island) ANOVA was carried out in addition to the LSD test as an a posteriori 1-way ANOVA (Sokal \& Rohlf 1995).

\section{RESULTS}

The examination of 202 pellets revealed 6396 identified items (Appendix 1). The most numerous prey came from the family Ammodytidae, accounting for $56 \%$ of all prey. Sandeels occurred in $73 \%$ of the pellets examined. The next most important prey were Atherina presbyter, which were present in $30 \%$ of the pellets and accounted for $10 \%$ of the prey, and the Gobiidae, which appeared in $16 \%$ of the pellets.
Additionally, 30 regurgitations of chicks were examined, of which 28 contained only sandeels (Ammodytidae), with a total of 44 individuals. The other 2 contained sandeels, a specimen of Symphodus cinereus and one of Callionymus lyra.

The diet composition was significantly different on the 2 islands $(G=1449$, $d f=6, p<0.0001)$. The main difference was due to the consumption of sandeels on the Cies Islands, where they comprised $76 \%$ of the prey and $42 \%$ of the biomass, whereas on the Island of Ons, they only made up $38 \%$ of the prey and $25 \%$ of the biomass. The differences in diet composition between Cies and Ons (Fig 2, Appendix 1) were significant during all months (Table 1). However, the differences between the islands decreased significantly as the reproductive season progressed (Spearman correlation between time in the breeding season and $G$-statistic: $\left.r_{s}=-0.90, \mathrm{df}=5, \mathrm{p}<0.05\right)$, with May being the month showing the greatest similarity in diet. 
Table 1 . G-statistic $(\cdots p<0.0001)$ obtained by the monthly comparison of the diet of the European shag Phalacrocorax aristotelis (in terms of numerical frequency) between the Islands of Cies and Ons. Also shown are the significant standardized residuals $(p<0.05)$ corresponding to each important prey (ns: $p>0.05)$

\begin{tabular}{lcccccc}
\hline & Ammodytidae & Atherinidae & Gobiidae & Labridae & Gadidae & $G$ \\
\hline Feb & 16.5 & 8.1 & 15.1 & ns & 5.7 & $1370 \cdots$ \\
Mar & 10.9 & 11.6 & 4.7 & ns & 2.2 & $642 \cdots$ \\
Apr & 3.3 & 4.3 & 3.0 & ns & 3.9 & $117 \cdots$ \\
May & ns & ns & ns & 2.7 & 2.1 & $45 \cdots$ \\
Jun & ns & 2.5 & & & 4.9 & $112 \cdots$ \\
\hline
\end{tabular}

Spatial differences in the consumption of sandeels decreased during the breeding period (Table 1), to the point where there were no significant variations in numerical frequency between the 2 islands in May and June (>70\% on both islands). The differences found at the beginning of the breeding period were due to the low appearance of sandeels on the Island of Ons in February (8\%), March (18\%) and April (57\%), as compared to the high frequency on the Cies Islands during the same period ( $>70 \%$ in all months). The Gadidae were the only group of prey that had significant differences between the 2 islands in all months. Gadids were more frequent in the diet of the European shag in February, March and June on the Cies Islands and in April and May on the Island of Ons. The variability in consumption of Atherina presbyter and Gobiidae between Cíes and Ons was significant during February, March and April. A. presbyter accounted for $57 \%$ of the diet on the Island of Ons in March, while on the Cíes Islands it did not reach values of over $5 \%$. The gobids accounted for 66 and $21 \%$ of the diet in February and March, respectively, on the Island of Ons, while on the Cies Islands they comprised less than $10 \%$ of the diet (the main prey species in this case was Gobiusculus flavescens). Labrids were present in the diet with the same frequency on the Islands of Cies and Ons in February, March and April, but showed significant spatial differences in May and June. Other prey, both fish and invertebrates, did not make any signifi- cant contributions to the differences in diet of the birds between the 2 colonies.

Table 2 presents the diversity indices $\left(H^{\prime}\right)$ of the diet of the European shag on the Islands of Cies and Ons throughout the breeding season. Individual diversity ( $H^{\prime}$ ind) varied significantly among months (KruskalWallis test: $\chi^{2}=11.78, \mathrm{df}=4, \mathrm{p}<0.05$ ), but not between the 2 islands (Mann-Whitney test: $U=422, \mathrm{p}>0.05$ ). Sandeels were the only prey whose abundance correlated negatively with the individual diversity index (Spearman rank correlation, $R_{s}=-0.70, p<0.05, N=$ 202), which implies that they tend to appear as the sole prey in the pellets. The rest of the prey correlated positively and significantly $(p<0.05)$ with the diversity index, the highest corresponding to Symphodus spp. $\left(\mathrm{R}_{\mathrm{s}}=0.59\right)$.

The population diversity index obtained using the jackknife method (Table 2) did not differ significantly between the islands (ANOVA: $F_{1.204}=0.01, \mathrm{p}>0.1$ ); however, there was a significant difference among months $\left(F_{4.204}=2.35, \mathrm{p}<0.05\right)$, with a significant interaction between both factors $\left(F_{4,204}=3.55, \mathrm{p}<0.01\right)$. On the Cies Islands, the temporal changes were not significant $\left(F_{4,129}=1.57, \mathrm{p}>0.1\right)$, though they were on the Island of Ons $\left\{F_{4,74}=6.34, p<0.001\right\}$. On the latter island the diversity in June differed significantly from the values found in February, March and April, and the diversity in May differed from that in March and April (LSD test, $p<0.05$ ).

Table 2. Indices of individual $\left(H^{\prime}{ }_{\text {ind }}\right)$ and population $\left(H_{\text {pop }}^{\prime}\right)$ dietary diversity of the European shag Phalacrocorax aristotelis, and the population index obtained using the jackknife method $\left(H_{\text {jack }}^{\prime}\right) . H_{\text {ind }}^{\prime}$ and $H_{\text {jack }}^{\prime}$ are expressed as mean $\pm \mathrm{SE}$

\begin{tabular}{|c|c|c|c|c|c|c|c|c|c|c|c|c|}
\hline & \multicolumn{2}{|c|}{ February } & \multicolumn{2}{|c|}{ March } & \multicolumn{2}{|c|}{ April } & \multicolumn{2}{|c|}{ May } & \multicolumn{2}{|c|}{ June } & \multicolumn{2}{|c|}{ Total } \\
\hline & Cíes & Ons & Cíes & Ons & Cies & Ons & Cíes & Ons & Cíes & Ons & Cíes & Ons \\
\hline$H_{\text {ind }}^{\prime}$ & $\begin{array}{r}0.60 \\
\pm 0.49\end{array}$ & $\begin{array}{r}0.52 \\
\pm 0.39\end{array}$ & $\begin{array}{r}0.31 \\
\pm 0.38\end{array}$ & $\begin{array}{r}0.44 \\
\pm 0.38\end{array}$ & $\begin{array}{r}0.20 \\
\pm 0.30\end{array}$ & $\begin{array}{r}0.73 \\
\pm 0.46\end{array}$ & $\begin{array}{r}0.30 \\
\pm 0.43\end{array}$ & $\begin{array}{r}0.33 \\
\pm 0.33\end{array}$ & $\begin{array}{r}0.40 \\
\pm 0.40\end{array}$ & $\begin{array}{r}0.27 \\
\pm 0.29\end{array}$ & $\begin{array}{r}0.39 \\
\pm 0.44\end{array}$ & $\begin{array}{r}0.47 \\
\pm 0.40\end{array}$ \\
\hline$H_{\text {pop }}^{\prime}$ & 1.20 & 1.15 & 0.98 & 1.41 & 0.55 & 1.40 & 0.78 & 0.57 & 1.01 & 0.49 & 1.08 & 1.51 \\
\hline$H_{\mathrm{jack}}^{\prime}$ & $\begin{array}{r}1.35 \\
+1.40\end{array}$ & $\begin{array}{r}1.03 \\
+1.05\end{array}$ & $\begin{array}{r}1.15 \\
\pm 1.56\end{array}$ & $\begin{array}{r}1.52 \\
\pm 0.75\end{array}$ & $\begin{array}{r}0.38 \\
\pm 0.81\end{array}$ & $\begin{array}{r}1.51 \\
\pm 1.04\end{array}$ & $\begin{array}{r}0.89 \\
\pm 1.38\end{array}$ & $\begin{array}{r}0.59 \\
\pm 0.56\end{array}$ & $\begin{array}{r}1.11 \\
\pm 0.78\end{array}$ & $\begin{array}{r}0.26 \\
\pm 0.30\end{array}$ & $\begin{array}{r}1.05 \\
\pm 1.29\end{array}$ & $\begin{array}{r}1.02 \\
\pm 0.93\end{array}$ \\
\hline
\end{tabular}



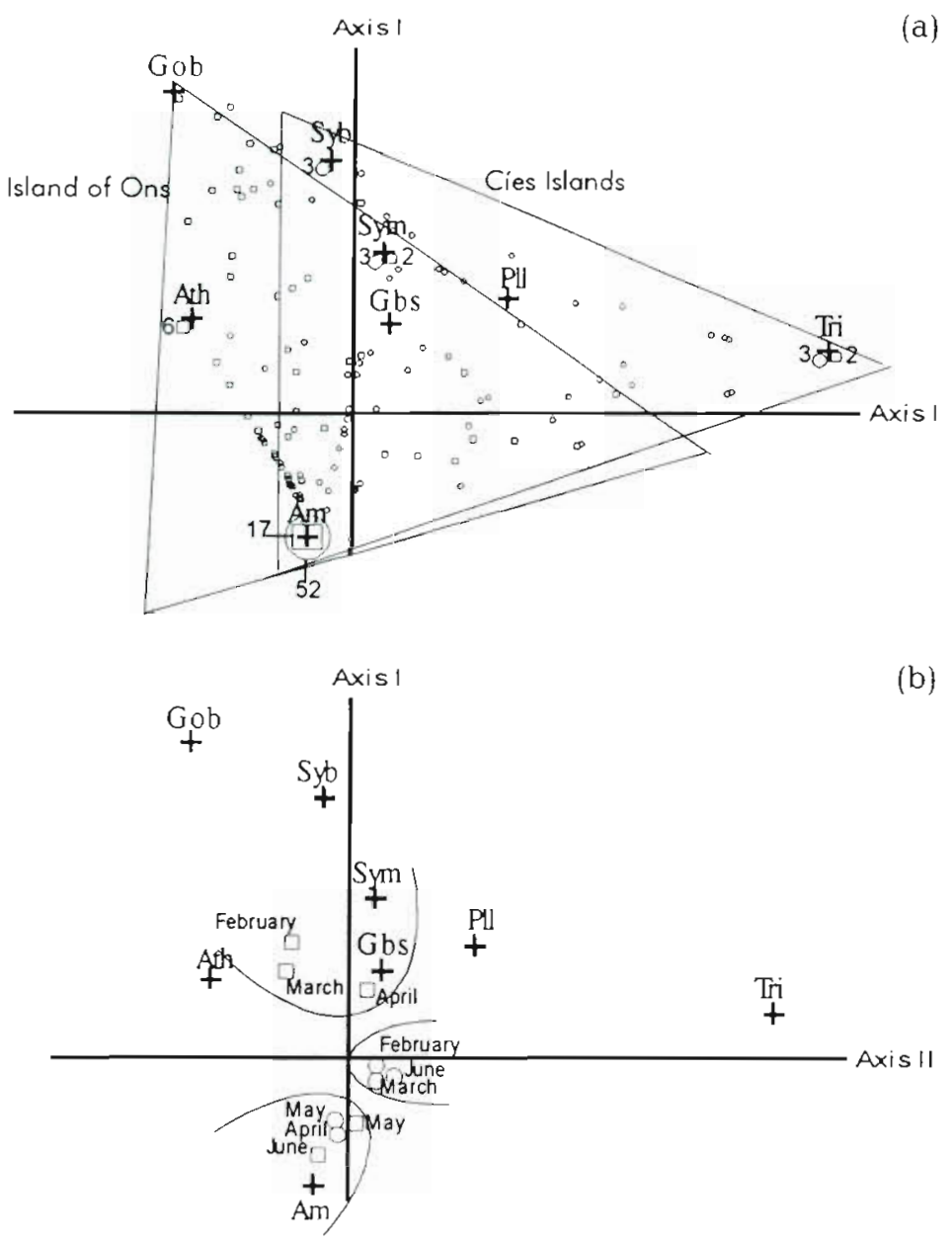

Fig. 3. Phalacrocorax aristotelis.Representation of Axes I and II extracted from the correspondence analysis of the diet of the European shag: (a) for all pellets (the numbers represent pellets with coinciding scores, and (b) for the mean scores corresponding to each month and location. (o) Samples from the Cies Islands; ( $\square$ ) samples from the Island of Ons. See prey codes in Appendix 1

A correspondence analysis was carried out on the diet of the European shag taking into account information on the numerical frequency of the dominant prey in the pellets (Fig. 3). The first 3 axes extracted explain $61 \%$ of the variance. Axis I (26\%) contrasts Ammodytidae with Gobius spp. and, to a lesser extent, with Symphodus bailloni. Axis II (20\%) is defined in its negative part by the pellets with high frequencies of Gobius spp. and Atherina presbyter and by Trisopterus spp. in its positive part. Axis III $(16 \%)$ contrasts Gobiusculus flavescens and, to a lesser extent, $S$. bailloni with $A$. presbyter. On the plane formed by Axes I and II, some of the pellets from the Islands of Cies and Ons showed a similar diet due to the great abundance of Ammodytidae, but on the Island of Ons Gobius spp. and $A$. presbyter had a higher frequency of occur- rence. In contrast, the diet on the Cies Islands tended to include more gadids, such as Pollachius pollachius and Trisopterus spp. Three groups of samples may be established in terms of the mean score for each month at the 2 locations (Fig. 3b). The first would be represented by early dates in the breeding season on the Island of Ons (February, March and April), which would have high positive scores on Axis I. The second group would include the early months (February and March) and June on the Cíes Islands, with intermediate scores on both axes. The third group, located in the negative area of Axis I, with a diet based on Ammodytidae, would be made up of the late months on the Island of Ons (May and June) and of the intermediate months on the Cies Islands.

The mean size (total length) $( \pm \mathrm{SE})$ of the prey caught by the European shag was $98.5 \pm 0.5 \mathrm{~mm}$, and was higher on the Cíes Islands $(104.0 \pm 0.7 \mathrm{~mm})$ than on the Island of Ons $(91.9 \pm 0.7 \mathrm{~mm})(t=11.74, \mathrm{p}<$ 0.01).

The sizes of the different species of fishes caught as prey by the European shag varied significantly (Fig. 4; ANOVA: $F_{46153}=298.9$, $p<0.0001$ ), and there were significant differences in the sizes of all species (LSD test, $p<0.05$ ), except between Symphodus spp. and Ammodytidae. However, if we compare the size-frequency distributions of each species on the archipelago, it is possible to observe that all cases present a modal size of 10 to $11 \mathrm{~cm}$. There were no significant differences between locations in the size of the sandeels consumed (ANOVA: $F_{1,3685}=1.41$, $p>0.05)$, but there were differences among months $\left(F_{4,3685}=22.1, \mathrm{p}<0.001\right)$; moreover there was a significant interaction between both factors $\left(F_{4,3685}=\right.$ 22.3, $\mathrm{p}<0.001)$. The modal size of this prey was around 9 to $10 \mathrm{~cm}$ in all the months (Fig. 5).

\section{DISCUSSION}

The main group of prey of the European shag on the Islands of Cíes and Ons is the family Ammodytidae, which accounts for $73 \%$ of the total number of prey consumed. The otoliths of this family are small and possibly more digestible and more difficult to recover in the samples than those of species having larger otoliths (Johnstone et al. 1990, Harris \& Wanless 1993), which implies that their numerical importance might 

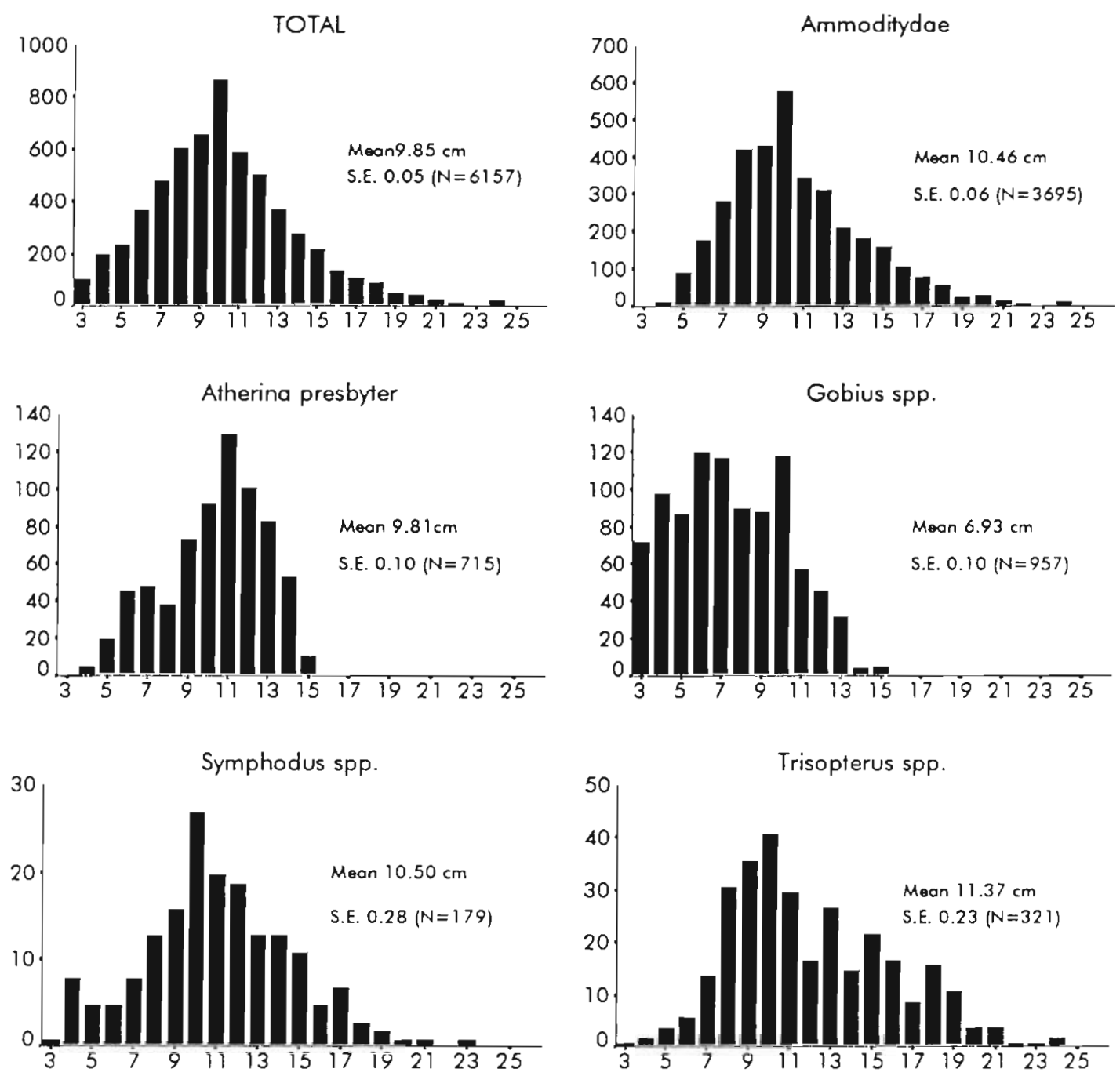

\section{FISH LENGTH $(\mathrm{cm})$}

Fig. 4. Phalacrocorax aristotelis. Size-frequency distributions (total length, $\mathrm{cm}$ ) of the different categories of fishes consumed by European shags from February to June 1995 on the Islands of Cíes and Ons. The mean ( \pm SE) size of each prey is given

be underestimated by sampling pellets regurgitated by shags. Ammodytidae are also the dominant prey in British populations of the European shag, and it is consistently present in the diets of shags in all locations studied in the NE Atlantic and Mediterranean, except in the case of the coast of Asturias ( $N$ Spain) (Table 3).

It has been suggested that the European shag is an opportunistic predator (Barret 1991) and that the variability in its dietary composition in different locations (Table 3 ) may be related to geographical differences in the availability of potential prey. Our study shows that the European shag has a high plasticity of feeding habitats, feeding on fish that are found in a diver- sity of habitats, including pelagic fish (such as Atherina presbyter), semipelagic fish from sandy bottoms (such as the family Ammodytidae), benthic species from sandy-mud bottoms (such as the family Gobiidae), as well as demersal and benthic fishes that live on rocky and sandy bottoms (such as Trisopterus spp. and the family Labridae). The dominant prey of the European shag in all geographical areas are Ammodytidae and Gadidae, although the Labridae acquire increasing importance in more southern locations (in the Mediterranean and in Asturias, N Spain). A. presbyster only appears as prey on the coasts of the Iberian Peninsula and in the Mediterranean, and is locally abundant. 
Table 3. Phalacrocorax aristotelis. Diet of the European shag in different locations of the NE Atlantic and Mediterranean. Data are expressed as percentage of frequency of occurrence $(*)$ or of numerical frequency $(\cdots)$, depending on the method used by the different authors (-: absence of prey or present in less than $0.1 \%$ )

\begin{tabular}{|c|c|c|c|c|c|c|c|}
\hline $\begin{array}{r}\text { Location } \\
\text { Source }\end{array}$ & mmodytidae & Atherinidae & Gobiidae & Clupedidae & Labridae & Gadidae & Other prey \\
\hline $\begin{array}{l}\text { Cornwall (England) } \\
\text { Steven (1933) }\end{array}$ & 51 & - & 2 & 30 & 13 & 3 & 14 \\
\hline $\begin{array}{l}\text { Farne }(\text { Scotland) } \cdot \cdot \\
\text { Pearson }(1968)\end{array}$ & 81 & - & $=$ & - & - & 4 & 15 \\
\hline $\begin{array}{l}\text { Clyde (Scotland) }{ }^{.} \\
\text {Lumsden \& Haddow (1946) }\end{array}$ & 78 & - & 3 & 0.6 & 1 & 13 & 4 \\
\hline $\begin{array}{l}\text { Loch Ewe (Scotland) } \cdot \\
\quad \text { Mills (1969) }\end{array}$ & 41 & - & - & - & - & 59 & - \\
\hline $\begin{array}{l}\text { Shetland (Scotland) } \\
\text { Harris \& Riddiford (1989) }\end{array}$ & 100 & - & - & - & - & - & - \\
\hline $\begin{array}{l}\text { lsle of May (Scotland) }{ }^{\circ} \\
\text { Harris \& Wanless }(1990)\end{array}$ & 95 & - & 11 & - & - & 45 & 15 \\
\hline $\begin{array}{l}\text { Hornøy (Norway) }{ }^{\circ} \\
\text { Barret et al. }(1990)\end{array}$ & 56 & - & - & - & - & 40 & 3 \\
\hline $\begin{array}{l}\text { Bleiksøy (Norwayj }{ }^{\circ} \\
\text { Barret et a]. (1990) }\end{array}$ & 15 & - & - & - & - & 69 & 16 \\
\hline $\begin{array}{l}\text { Rogaland (Norway) }{ }^{\cdot} \\
\text { Barret et al. }(1990)\end{array}$ & 15 & - & - & - & 20 & 50 & 15 \\
\hline $\begin{array}{l}\text { Corcega (Corsica) } \\
\text { Guyot }(1988)\end{array}$ & 33 & 5 & - & - & 78 & - & 28 \\
\hline $\begin{array}{l}\text { Caladoria (Asturias, NW Spain) “ } \\
\text { Álvarez (1998) }\end{array}$ & - & 35 & - & - & 52 & 11 & 2 \\
\hline $\begin{array}{l}\text { Islands of Cies (Galicia, NW Spain) }{ }^{\circ} \\
\text { This study }\end{array}$ & • 75 & 3 & 6 & - & 5 & 7 & 4 \\
\hline $\begin{array}{l}\text { Island of Ons (Galicia, NW Spain) " } \\
\text { This study }\end{array}$ & 38 & 20 & 30 & - & 5 & 4 & 3 \\
\hline
\end{tabular}

Despite the variability observed in the colonies, the present study shows that the diet converges towards the family Ammodytidae during chick provisioning (primarily in May but also in April and June; Fig. 3), which would bring about a reduction in dietary diversity. Moreover, there is a negative correlation of the diversity of each pellet with the presence of Ammodytidae and a positive correlation with the remainder of the prey. This would appear to indicate that the European shag forages mainly for sandeels on these islands, which coincides with what has been observed in other areas (Table 3). The fish belonging to this family form schools which have a high density in late spring on the British coasts (Reary 1973) and a large number of seabirds depend on these fishes (see Furness 1990, Wright 1996). The seasonal changes in the abundance of schools might explain the temporal changes in diet, giving rise to a greater specialization when this resource is abundant. Harris \& Wanless (1993) report that chicks are fed exclusively Ammodytes tobianus on the Isle of May (Scotland). On the Cíes Islands the diet observed in the pellets is more diverse than the regurgitations of the chicks, which are made up almost exclusively of sandeels. This implies that parents feed on prey different than those they provide to chicks.

The European shag has a greater dietary diversity in February and March. The diet consumed on the Cies Islands is similar throughout all the months, though on the Island of Ons during the winter the diet is based on Atherina presbyter and Gobius spp. There are very few studies on $A$. presbyster, but it appears to be one of the most abundant species of coastal pelagic fish in the waters off the Galician coasts (Lens 1986). The family Gobiidae is dominant in the rias of Arousa and Pontevedra (Chesney \& Iglesias 1979, Iglesias 1981, Igle- 

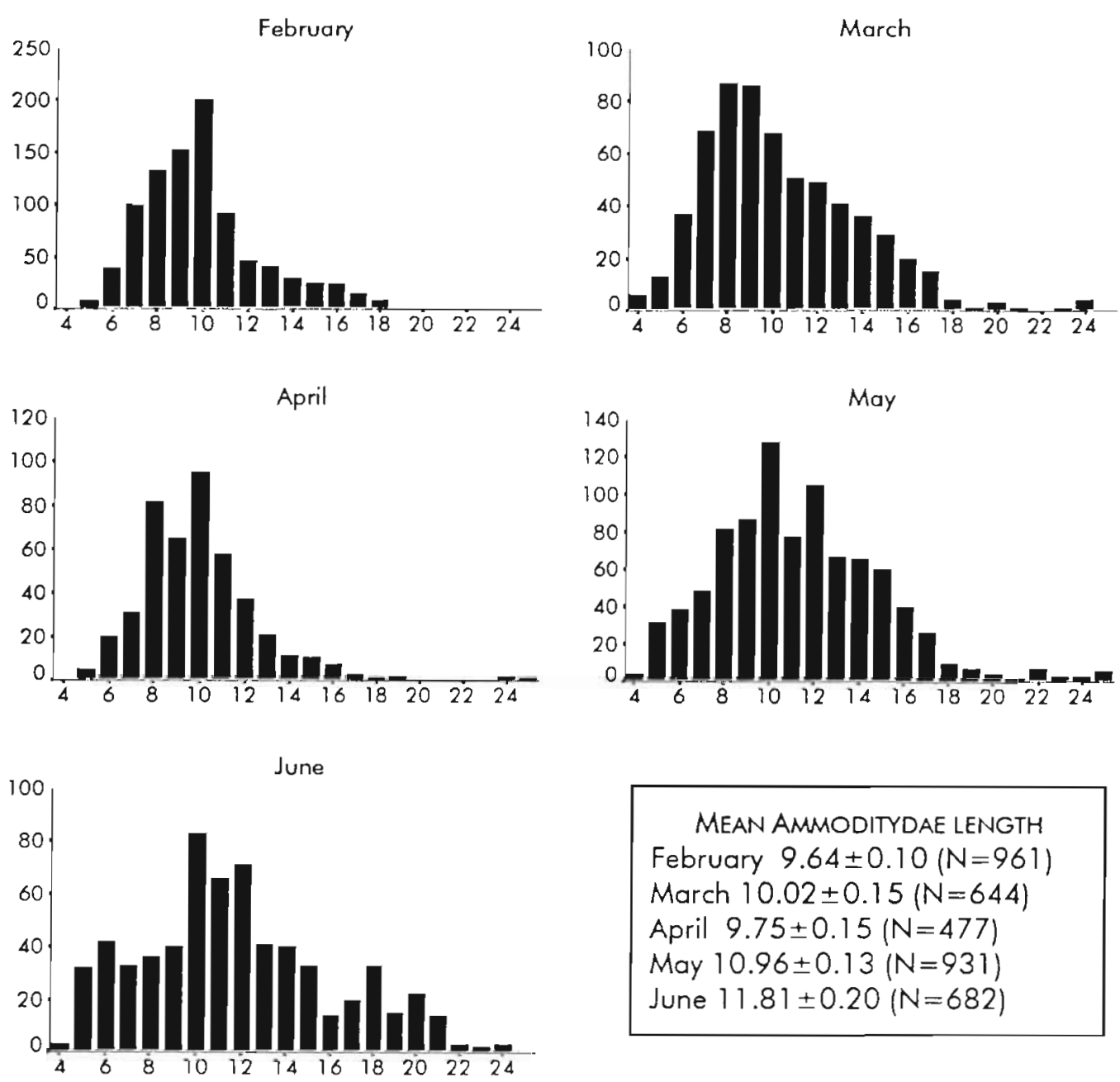

\begin{tabular}{|l|}
\hline MEAN AMMODITYDAE LENGTH \\
February $9.64 \pm 0.10(\mathrm{~N}=961)$ \\
March $10.02 \pm 0.15(\mathrm{~N}=644)$ \\
April $9.75 \pm 0.15(\mathrm{~N}=477)$ \\
May $10.96 \pm 0.13(\mathrm{~N}=931)$ \\
June $11.81 \pm 0.20(\mathrm{~N}=682)$
\end{tabular}

FISH LENGTH $(\mathrm{cm})$

Fig. 5. Phalacrocorax aristotelis. Temporal evolution of the size-frequency distributions (total length, $\mathrm{cm}$ ) of the sandeels consumed by European shags from February to June 1995 on the Cies Islands and the Island of Ons. The mean ( \pm SE) size is given for each month

sias \& González-Gurriarán 1984), with Lesueurigobius friesii being the most abundant species (in this study L. friesii is included with Gobius spp.). Fernandez (1994) observed maxima in the abundance of this species in January and August in the Ría de Arousa, and Iglesias \& González-Gurriarán (1984) reported densities as high as 0.57 individuals $\mathrm{m}^{-2}$ in the Ría de Pontevedra in February. The abundance of this species during the winter could explain why it is consumed by European shags on the Island of Ons. Iglesias \& González-Gurriarán (1984) located this species in the outer area of the Ría de Pontevedra, which is used as a feeding area by shags from the Island of Ons (Velando 1997), while Gobius niger is found in the inner area of the ría.
Seasonal changes in diet may also be attributed to a change in feeding grounds (Lumsden \& Haddow 1946). Sandeels occupy large sandy areas (Reary 1973) and therefore European shags catch this fish only where sand banks are near colonies (Lumsden \& Haddow 1946, Wanless et al. 1991b). Ammodytids are poorly documented on the Galician coast, with the most abundant species being Hyperoplus lanceolatus and Gymnammodytes semisquamatus (see review in Solórzano et al. 1988). These species are likely to have been underestimated in studies of fish communities because of the type of trawl nets used in the samplings (for example, Iglesias 1981, Guerra \& Pérez Gándaras 1987). The present paper indicates that this family is abundant in the 2 rias and the adjacent coast, probably 
linked to the sandy areas surrounding both islands (Vilas et al. 1995, 1996). The evident contradiction between studies of fish communities and the present analysis of the shag's diet may be due to 2 main reasons: (1) the low ability of the trawl nets used for fish community studies to catch sandeels, related to the benthopelagic habits of sandeels; and (2) previous studies have overlooked habitats characteristic of sandeels which occupy restricted areas but play an important role in the coastal ecosystem, as the present study documents. The last point corroborates the value of studies of seabird diet as indicators of prey abundance (Cairns 1987, Barret et al. 1990, Hatch \& Sanger 1992, Montevecchi \& Myers 1995).

The family Gadidae, particularly Trisopterus spp., is an important element in the diet of European shags, especially in terms of its contribution to the biomass consumed. Although it accounts for only $5 \%$ of the prey, it comprises $16 \%$ of the biomass. The genus Trisopterus is abundant in Galician rías, showing a maximum abundance in summer (Iglesias 1981). It has abundance peaks in the diet in April on the Island of Ons and in June on the Cies Islands (13 and $15 \%$ of the numerical frequency, respectively).

The estimated mean size of prey from the Islands of Cíes and Ons is $9.8 \mathrm{~cm}$, which is similar to the size of $9.7 \mathrm{~cm}$ estimated on the Isle of May (Wanless et al. 1993b), although the mean prey size in this location varies from year to year (Wanless et al. 1993a). In contrast, Barret et al. (1990) reported variations in mean prey length among Norwegian populations, Ammodytidae ranging from 10 to $12 \mathrm{~cm}$ and the gadids from 6 to $14 \mathrm{~cm}$.

In our study, for all prey species from the 2 islands the modal length was $10 \mathrm{~cm}$. In Norway, the modal prey length varied with species: $9 \mathrm{~cm}$ in Ammodytes sp. and from 6 to $14 \mathrm{~cm}$ in gadids, depending on the colony (Barret et al. 1990). On the Isle of May, the modal prey lengths were 6 and $8 \mathrm{~cm}$ (Wanless et al. 1993b). The prey length on the Cíes Islands suggests that European shags selected a restricted range of prey size, especially during April and May, when there were no prey size differences between the 2 islands. Moreover, the available sizes of prey differ from those selected by the shags. The lengths of gobiids eaten by shags differ from those of Lesueurigobius friesii in the Ría de Arousa. European shags consume gobiids ranging mainly between 4 and $10 \mathrm{~cm}$, with a bimodal distribution with modes of 6 to 7 and $10 \mathrm{~cm}$. The population of $L$. friesii in the Ría de Arousa has a dominant modal group of around $7 \mathrm{~cm}$, while the $10 \mathrm{~cm}$ group is much less abundant (Fernández 1994). The mean length of Trisopterus luscus individuals caught on the continental shelf off Galicia was $19 \mathrm{~cm}$, with the most abundant modal class being
$23 \mathrm{~cm}$ in length (López-Veiga et al. 1976, 1977). Individuals in the rías have much larger mean lengths than those in the diet of shags (J. E. Ortega-Ruano \& J. Freire unpubl. data), as the shag captures primarily juveniles measuring less than $11 \mathrm{~cm}$ with a bimodal distribution with modes of 10 and $15 \mathrm{~cm}$. European shags appear to select small fish. Shags capture fishes with bills which work like tweezers (Lumsden \& Haddow 1946), and there is a strong sexual dimorphism in size (males weigh $22 \%$ more than females), although the bill does not show dimorphism. This fact has been suggested as a possible selective force for an optimum bill size in both sexes (Velando et al. unpubl.), which is determined by the need to capture prey of a particular size.

Our study highlights differences in the diets of the European shag in 2 colonies near to one another. The diet was found to have greater divergence and diversity during the winter, which could be a reflection of the greater diversity in feeding grounds used by this species in winter. During this season, the competition between individuals and the scarcity of prey may give rise to a more opportunistic diet, especially if we consider that these birds are able to exploit areas further away from the colonies. In contrast, during the months when the chicks are being provisioned, the diet centers around the family Ammodytidae, and the birds exploit a resource which is abundant in the sandy areas that surround the islands. The feeding grounds on the Cies Islands are located within a radius of less than $2 \mathrm{~km}$ from the colonies, on sandy bottoms at mean depths of less than $14 \mathrm{~m}$ (Velando 1997). Additionally, the distribution in size of the prey consumed points to the selection of prey by size (since the size-frequency distribution in the field is different). Therefore, this study has found that the European shag presents characteristics typical of an opportunistic feeder, but is highly selective in its use of a specific resource, depending on the ecological conditions, during the chick feeding period.

Acknowledgements. We thank the Electron Microscopy Unit, Universidade da Coruna, for the facilities. This study was partially funded by the Servicio de Medio Ambiente Natural, Xunta de Galicia.

\section{LITERATURE CITED}

Aebischer NJ, Wanless S (1992) Relationships between colony size and enviromental conditions for Shags Phalacrocorax aristotelis on the Isle of May, Scotland. Bird Study 39:43-52

Álvarez D (1998) The diet of shags Phalacrocorax aristotelis L. in the Cantabrian sea (North of Spain) during the breeding season. Seabird 20:22-30

Ashmole NP (1971) Seabird ecology and the marine environ- 
Appendix 1. Seasonal patterns in dietary composition of the European shag Phalacrocorax aristotelis, expressed as numerical frequency $(\% \mathrm{~N})$, on the Cíes Islands and Island of Ons during the period under study in 1995. Prey codes used in Fig. 3 are given in parentheses

\begin{tabular}{|c|c|c|c|c|c|c|c|c|c|c|c|c|}
\hline & \multicolumn{2}{|c|}{ February } & \multicolumn{2}{|c|}{ March } & \multicolumn{2}{|c|}{ April } & \multicolumn{2}{|c|}{ May } & \multicolumn{2}{|c|}{ June } & \multicolumn{2}{|c|}{ Total } \\
\hline & Cíes & Ons & Cíes & Ons & Cíes & Ons & Cies & Ons & Cíes & Ons & Cies & Ons \\
\hline No. of pellets & 30 & 18 & 28 & 17 & 14 & 14 & 30 & 14 & 25 & 12 & 127 & 75 \\
\hline No. of items & 1246 & 1078 & 711 & 653 & 300 & 389 & 650 & 469 & 578 & 322 & 3485 & 2911 \\
\hline Ammoditydae (Am) & 71.2 & 8.5 & 75.8 & 17.6 & 86.0 & 57.3 & 83.2 & 86.6 & 71.4 & 87.3 & 757 & 38.5 \\
\hline $\begin{array}{l}\text { Atherinidae } \\
\text { Atherina presbyter (Ath) }\end{array}$ & 2.0 & 16.0 & 4.2 & 50.1 & - & 11.6 & 4.1 & 4.0 & 5.5 & 9.3 & 3.2 & 20.3 \\
\hline Gobiidae & & & & & & & & & & & & \\
\hline Gobius spp. (Gob) & 2.0 & 65.8 & 7.4 & 21.0 & - & 5.9 & 1.4 & - & 0.2 & - & 2.5 & 29.8 \\
\hline Gobiusculus flavescens (Gibs) & ) 9.6 & - & 0.1 & - & - & - & - & - & 0.3 & - & 3.5 & - \\
\hline Labridae & & & & & & & & & & & & \\
\hline Symphodus spp. (Sym) & 2.7 & 4.2 & 3.2 & 2.6 & 8.3 & 7.2 & 4.5 & 1.0 & 3.1 & 0.3 & 3.7 & 3.2 \\
\hline Symphodus bailloni (Syb) & 1.4 & 0.4 & $0 . \bar{t}$ & 4.0 & & 2.6 & 1.1 & - & 2.1 & - & 1.2 & 1.4 \\
\hline Labrus spp. & 0.5 & 0.2 & 0.4 & 0.5 & 0.3 & 0.3 & - & 0.2 & - & - & 0.3 & 0.2 \\
\hline Gadidae & & & & & & & & & & & & \\
\hline Trisopterus spp. (Tri) & 4.4 & 0.1 & 5.6 & 2.8 & 4.0 & 13.1 & 2.6 & 6.0 & 15.2 & 0.6 & 6.1 & 3.4 \\
\hline Pollachius pollachius (Pll) & 2.2 & 0.2 & 2.0 & 0.6 & 0.7 & 1.3 & 0.9 & 2.3 & 0.3 & - & 1.5 & 0.7 \\
\hline Cilia mustelata & 0.2 & - & 0.1 & 0.1 & - & - & 0.3 & 0.2 & - & - & 0.2 & 0.1 \\
\hline Micromesistius spp. & - & $=$ & - & - & - & - & - & - & 0.3 & - & 0.1 & - \\
\hline Other fishes & & & & & & & & & & & & \\
\hline Sardina pilchardus & 0.1 & - & - & - & 0.7 & - & 0.1 & - & 1.2 & 2.1 & 0.3 & 0.2 \\
\hline Chelon labrosus & - & 2.5 & - & - & - & - & - & - & - & - & - & 0.9 \\
\hline Callionymus lyra & 1.6 & - & - & - & - & 0.5 & 0.3 & - & - & - & 0.6 & 0.1 \\
\hline Scomber scombrus & 0.3 & - & - & - & - & - & 0.5 & - & - & - & 0.2 & - \\
\hline Scorphaena spp. & 0.2 & - & - & - & - & - & - & - & - & - & 0.1 & - \\
\hline Unidentified & 0.2 & 0.1 & 0.3 & 0.5 & - & 0.3 & 1.0 & - & 0.2 & 0.3 & 0.3 & 0.2 \\
\hline Crustacea & 0.5 & 1.0 & - & 0.3 & - & - & - & - & - & - & 0.2 & 0.4 \\
\hline Cephalopoda & 0.2 & 1.0 & - & - & - & - & - & - & - & - & 0.1 & 0.4 \\
\hline
\end{tabular}

ment, In: Farner DS, King JR (eds) Avian Biology, Vol I. Academic Press, New York, p 224-271

Barret RT (1991) Shags (Phalacrocorax aristotelis L.) as potential samplers of juvenile saithe (Pollachius virens L.) stocks in Northern Norway. Sarsia 76:153-156

Barret RT, Furness RW (1990) The prey and diving depths of seabirds on Hornoy, North Norway after a decrease in the Barents Sea Capelin stocks. Ornis Scand 21:179-186

Barret RT, Schei PJ (1977) Changes in the breeding distribution and numbers of cliff-breeding seabirds in Sør-Varanger, North Norway. Astarte 10:29-35

Barret RT, Røv N, Loen J, Montevecchi WA (1990) Diets of shags Phalacrocorax aristotelis and cormorants $P$. carbo in Norway and possible implications for gadoid stock recruitment. Mar Ecol Prog Ser 66:205-218

Bauza (1962) Contribución al estudio de los otolitos de peces. Bol R Soc Esp Hist Nat (Biol) 60:5-26

Bernis $F(1948)$ Las aves de las islas Sisargas en junio. Bol R Soc Esp Hist Nat (Biol) 76:647-684

Cairns DK (1987) Seabirds as indicators of marine food suplies. Biol Oceanogr 5:261-271

Carss DN (1993) Shags Phalacrocorax aristotelis at cage fish farms in Argyll, Western Scotland. Bird Study 40:203-211

Chesney EJ, Iglesias J (1979) Seasonal distribution, abundance and diversity of demersal fishes in the inner Ría de Arosa, Northwest Spain. Estuar Coast Mar Sci 8:227-239

Croxall JP (1987) Seabirds: feeding ecology and the role in marine ecosystems. Cambridge University Press, Cambridge

Croxall JP, Prince PA, Ricketts C (1985) Relationships between prey life cycles and the extent, nature and timing of seal and seabird predation in the Scotia Sea. In: Siegfrield WR, Condy PR, Laws RM (eds) Antarctic nutrient food cycles and food webs. Springer-Verlag, Berlin, p 516-533

Duffy DC, Jackson S (1986) Diet studies of seabirds: a review of methods. Colon Waterbirds 9:1-17

Duffy DC, Laurenson LJB (1983) Pellets of Cape Cormorants as indicators of diet. Condor 85:305-307

Fernández L (1994) Alimentación de los peces demersales en la Ría de Arousa: influencia del cultivo del mejillón. PhD thesis, Universidade da Coruña, A Coruña

Furness RW (1990) A preliminary assessment of the quantities of Shetland sandeels taken by seabirds, seals, predatory fish and the industrial fishery in 1981-83. Ibis 132:205-217

Grémillet D, Schulte B, Culik BM (1998) Flexible foraging techniques in breeding cormorants Phalacrocorax carbo and shags Phalacrocorax aristotelis: benthic or pelagic feeding? lbis 140:113-119

Guerra A, Pérez-Gándaras G (1987) Especies demersales y bentónicas de la ría de Vigo. Resultados preliminares. Instituto de Investigaciones Marinas, Vigo

Guyot I (1988) Relationships between shag feeding areas and human fishing activities in Corsica (Mediterranean Sea) 
In: Tasker ML (ed) Seabird food and feeding ecology. Proceedings of the 3rd International Conference of the Seabird Group. Seabird Group, Sandy, p 22-23

Härkönen (1986) Guide to the otoliths of the bony fishes of northeast Atlantic. Danbiu A.ps Hellerup, Denmark

Harris MP, Riddiford NJ (1989) The food of some young seabirds on Fair Isle in 1986-88. Scottish Birds 15:119-125

Harris MP, Wanless S (1990) Breeding success of British Kitiwakes Rissa tridactyla in 1986-1988. J Appl Ecol 27:172-187

Harris MP, Wanless S (1991.) The importance of the lesser sandeel Ammodytes marinus in the diet of shag Phalacrocorax aristotelis. Ornis Scand 22:375-382

Harris MP, Wanless S (1993) The diet of Shags Phalacrocorax aristotelis during the chick-rearing period assessed by three methods. Bird Study 40:135-139

Hatch SA, Sanger GA (1992) Puffins as samplers of juvenile pollock and other forage fish in the Gulf of Alaska. Mar Ecol Prog Ser 80:1-14

Huntley ME, López MDG, Karl DM (1991) Top predators in the Southern Ocean: a major leak in the biological carbon pump. Science 253:64-66

Iglesias J (1981) Spatial and temporal changes in the demersal fish community of the Ría de Arosa (NW Spain). Mar Biol 65:199-208

Iglesias J, González-Gurriarán E (1984) Primeros datos sobre la megafauna bentónica de la Ría de Pontevedra: peces demersales y crustáceos decápodos (Brachyura). Cuad Area Cienc Mar Sem Estud Galegos 1:303-319

Jobling M, Breiby A (1986) The use and abuse of fish otholiths in studies of feeding habits of marine psicivorous. Sarsia 71:265-274

Johnstone IG, Harris MP, Wanless S, Graves JA (1990) The usefulness of pellets for assessing the diet of adult Shags Phalacrocorax aristotelis. Bird Study 3:5-11

Krebs CJ (1989) Ecological methodology. Harper Collins, New York

Lens S (1986) Alimentación del pejerrey, Atherina presbyter Cuvier, en la Ría de Arosa. Bol Inst Esp Oceanogr 3:11-36

Lloyd CS, Tasker ML, Partridge KE (1991) The status of seabirds in Britain and Ireland. $T$ and Poyser, London

López Veiga EC, Labarta $E_{1}$ Alonso-Allende JM, Pérez-Gándaras G. Tourón J (1976) Distribución y abundancia de especies bentónicas de Galicia. Resultados de la campaña Galicia I (Sep 1974). Res Exp Cient B/O 'Cornide' 42:1-20

López Veiga EC, Vázquez A, Labarta E, Alonso-Allende JM, Fuertes JR, Pérez-Gándaras G, Tourón J (1977) Análisis de la pesquería demersal de Galicia II (Ag-Sep. 1975). Res Exp Cient $B / O$ 'Cornide' 6:65-133

Lumsden WHR, Haddow AJ (1946) The food of the shag (Phalacrocorax aristotelis) in the Clyde sea area. J Anim Ecol $15: 35-42$

Mills D (1969) The food of the shag in Loch Ewe, Ross-shire Scottish Birds 5:264-268

Monaghan P (1996) Relevance of the behaviour of seabirds to the conservation of marine environments. Oikos 77:227-237

Montevecchi WA, Myers RA (1995) Prey harvests of seabirds reflect pelagic fish and squid abundance on multiple spatial and temporal scales. Mar Ecol Prog Ser 117:1-9

Montevecchi WA, Myers RA (1996) Dietary changes of seabirds indicate shifts in pelagic food webs. Sarsia 80:313-322

Montevecchi WA, Myers RA (1997) Centurial and decadal oceanographic influences on changes un northern gannet populations and diets in the north-west Atlantic: implications for climate change. ICES J Mar Sci 54:608-614

Ollason JC, Dunnet GM (1983) Modelling annual changes in numbers of breeding Fulmars, Fulmarus glacialls, at a colony in Orkney. J Anim Ecol 52:185-198
Pearson TH (1968) The feeding biology of sea-bird species breeding on the Farne Islands, Northumberland. J Anim Ecol 37:53-1.02

Pierce GJ, Boyle PR (1991) A review of methods for diet analysis in piscivorous marine mammals. Oceanogr Mar Biol Annu Rev 29:409-486

Rae BB (1969) The food of cormorants and shags in Scottish estuarine and coastal waters. Mar Res Dep Agric Fish Scotland 1:1-16

Reary PJ (1973) Some aspects of the biology of the sandeel, Ammodytes tobianus L., In Langstone Harbour, Hampshire. J Mar Biol Assoc UK 53:325-346

Schneider D, Hunt GL Jr, Harrison NM1 (1985) Mass and energy transfer to seabirds in southeastern Bering Sea Cont Shelf Res 5:421-257

Snow B (1960) The breeding biology of the shag Phalacroco rax aristotelis on the island of Lundy, Bristol Channel. Ibis 102:554-575

Sokal RR, Rohlf FJ (1995) Biometry, 3rd edn. Freeman, New York

Solórzano MR, Rodríguez JL, Iglesias J, Pereiro FX, Álvarez F (1988) Inventario dos peixes do litoral galego (Pisces Cyclostomata, Chondrichthyes, Osteichthyes\}. Cadernos da Área de Ciencias Biolóxicas - Inventarios, Vol IV. Seminario de Estudios Galegos, O Castro-Sada, A Coruña

Steven J (1933) The food consumed by shags and cormorants around shores of Cornwall (England). J Mar Biol Assoc UK 19:277-292

ter Braak CJF (1988) CANOCO - a Fortran program for canonical ordination by [partial][detrended][canonical] correspondence analysis, principal component analysis and redundancy analysis. Agricultural Mathematics Group Wageningen

Tramer EJ (1969) Bird species diversity: components of Shannon's formula. Ecology 50:927-929

Velando A (1997) Ecología y comportamiento del cormorán moñudo Phalacocorax aristotelis en las Islas Cies y Ons PhD thesis. Universidade de Vigo, Vigo

Vilas F, Nombela MA, García-Gil E, García-Gil I, Alejo I Rubio B, Pazos O (1995) Cartografía de sedimentos submarinos. Ría de Vigo. Xunta de Galicia, Conselleria de Pesca, Marisqueo e Acuicultura, Santiago de Compostela

Vilas F, García-Gil E, García-Gil S, Nombela MA, Alejo I, Rubio $B$, Pazos O (1996) Cartografía de sedimentos submarinos. Ría de Pontevedra. Xunta de Galicia, Conselleria de Pesca, Marisqueo e Acuicultura, Santiago de Compostela

Wanless S, Burger AE, Harris MP (1991a) Diving depths of shags Phalacrocorax aristotelis breeding on Isle of May. Ibis 133:37-42

Wanless S, Harris MP, Morris JA (1991b) Foraging range and feeding locations of shags (Phalacrocorax aristotelis) during chick rearing. lbis 133:37-42

Wanless S, Corfield T, Harris MP, Buckland ST, Morris JA (1993a) Diving behaviour of the shag Phalacrocorax aris. totelis in relation to water depth and prey size. J Zool Lond 231:11-25

Wanless S, Harris MP, Russell S (1993b) Factors influencing food-load sizes brought in by shags Phalacrocorax aristotelis during chick rearing. Ibis 135:19-24

Wanless S, Harris NIP, Burger AE, Buckland ST (1997) Use of time-at-depth recorders for estimating depth and diving performance of European shags. J Field Ornithol 68: $547-561$

Wright PJ (1996) Is there a conflict between sandeel fisheries and seabirds? A case study at Shetland. In: Greenstreet SPR, Tasker ML (eds) Aquatic predators and their prey. Fishing News Books, Blackwell Science, Oxford, p 154-165 